Karol Lopatecki

\title{
Cywilna jurysdykcja wobec wojskowych w Koronie na przełomie XVI i XVII stulecia
}

\begin{abstract}
Summary
We can observe the process of determining the competence of military courts in Poland in the second half of the 16th century. They were competent to decide in all cases in which at least one of the parties was a military man. There were problems with these courts, so Polish noblemen decided to establish new courts for cases in which one party was a soldier and second was civilian (mixed cases). This reforms have been implemented since 1567 and from this time the civil courts could also decide in such cases. Another important aspect is connected with strict liability of commanders for their soldiers.

Polish noblemen didn't want to accept the commanders' jurisdiction in mixed cases. After 1578, when the supreme Crown Tribunal (Trybunał Koronny) was established, they struggled for giving the competence to this civil court in mixed cases. They succeed in 1593, although even after this date there were political disputes about the competence of civil jurisdiction.
\end{abstract}

\section{Wstęp}

Wybitny teoretyk i praktyk wojskowości Carl von Clausewitz stwierdził, iż żołnierze służący w wojskach stałych, muszą wyróżniać się od ogółu społeczeństwa organizacją, obyczajami i prawami ${ }^{1}$. Teza ta doskonale wkomponowuje się

${ }^{1}$ C. Clausewitz, O wojnie, tłum. A. Cichowicz, L. Koc, t. 1, Warszawa 1958, s. 157-159. 
w strukturę wojsk koronnych, od reform kwarcianych nieprzerwanie istniejących do upadku Rzeczypospolitej².

Historycy prawa, analizujący sądownictwo wojskowe, wskazują na jego szczególny charakter ${ }^{3}$. Podkreślają szerokie kompetencje jurysdykcji wojskowej do rozpatrywania spraw, które wykraczały poza grupę zawodową żołnierzy ${ }^{4}$. Zwracają uwagę na sądy wojskowe uprawnione do rozstrzygania spraw w sytuacji, gdy jedną ze stron był żołnierz, dostrzegając w tym privilegium fori stanu żołnierskiego ${ }^{5}$. Jednakże w przedmiocie tym „naród polityczny” stworzył daleko idące wyjątki. Interesujące są przyczyny wyłączenia niektórych materii spod sądownictwa wojskowego a zarazem ingerencji cywilnej jurysdykcji przede wszystkim w sprawy pomiędzy żołnierzami a szlachtą ${ }^{6}$. Zbadanie tych czynników wydaje się istotne, zważywszy na brak szczegółowych analiz ${ }^{7}$, a także literaturę przedmiotu niejednokrotnie podającą tezy nie znajdujące potwierdzenia w źródłach ${ }^{8}$.

${ }^{2}$ Wobec licznych odmienności tak w powstawaniu, jak i regulacjach prawnych armii Wielkiego Księstwa Litewskiego nie rozszerzamy naszych badań na ziemie całej Rzeczypospolitej. G. Lesmaitis, Lietuvos Didžiosios Kunigaikštystés samdomoji kariuomené XV a. pabaigos - 1570 m., Kaunas 2005, passim.

${ }^{3}$ J. Rafacz, Dawny proces polski, Warszawa 1925, s. 15, 21-22 stosuje termin „wyjątkowy”. Wart wskazania jest pogląd S. Grodziskiego, Z dziejów staropolskiej kultury prawnej, Kraków 2004, s. 191, utożsamiający prawo wojskowe z prawem ziemskim. Ta kontrowersyjna teza wymaga polemiki i dalszych badań.

${ }^{4}$ W. Organiściak, Kodeksy wojskowe w Polsce roku 1775, Katowice 2001, s. 175-180; J. Kamiński, Historia sądownictwa wojskowego $w$ dawnej Polsce, Warszawa 1928, s. 71.

${ }^{5}$ W. Bojarski, Z. Naworski, Jan Jelonek Cervus z Tucholi i jego twórczość prawnicza, Toruń 1993, s. 74. Pogląd ten rozpowszechnił S. Brodowski, Corpus iuris militaris Polonicum, Elbląg 1753, s. 40, 42, $44,46,48$.

${ }^{6}$ Stosujemy termin ,jurysdykcja cywilna” na określenie organów sądowych znajdujących się poza wojskową strukturą. Alternatywnie posługujemy się terminem „sądy powszechne" a contrario do sądownictwa wojskowego. Nie chcemy przy tym wprowadzić do pracy błędu ahistoryzmu (sądy powszechne powstały wskutek zniesienia sądownictwa stanowego, w okresie Księstwa Warszawskiego: W. Sobociński, M. Senkowska-Gluck, Księstwo Warszawskie, [w:] Historia państwa i prawa Polski, t. 3, J. Bardach, M. Senkowska-Gluck (red.), Warszawa 1981, s. 123), ile - posługując się dzisiejszą terminologią prawną - opisać zjawisko istniejące w okresie nowożytnym.

${ }^{7}$ Zagadnieniem stosunku do kodyfikacji z 1775 r. zajmował się W. Organiściak, Z badań nad zagadnieniem obowiązywania "Artykułów wojskowych" i „Procederu prawnego wojskowego" $z 1775$ roku, [w:] $Z$ dziejów prawa, cz. 2, A. Lityński (red.), Katowice 1999, s. 101-105; idem, Kodeksy wojskowe, op. cit., s. 174-183. Analizował to zjawisko również W. Maisel, Trybunał Koronny w świetle laudów sejmikowych i konstytucji sejmowych, „Czasopismo Prawno-Historyczne” 1982, t. 34, nr 2, s. 94-95, nie zauważając jednak alternatywnej właściwości sądów grodzkich, trybunalskich z sądami wojskowymi. Pobieżnej analizy dokonał S. Kempski, Władza buławy, „Przegląd Historyczno-Wojskowy” 1935, t. 7, nr 2, s. 193-194. W. Organiściak, O postępowaniu cywilnym w sq̨downictwie wojskowym Rzeczypospolitej w XVIII wieku, [w:] Z dziejów prawa, cz. 4, A. Lityński (red.), Katowice 2003, s. 53, przypis 2 uznał to zagadnienie za wymagające szczegółowego zbadania.

${ }^{8}$ J. Kamiński, Urzędy hetmańskie, [w:] Księga pamiątkowa ku czci Władysława Abrahama, t. 1, Lwów 1930, s. 311, twierdzi, iż do XVIII w. żołnierze w sprawach spornych z udziałem czynnika cywil- 
Istota sporu i zasadnicze rozstrzygnięcia kształtowały się w okresie pomiędzy 1567 a 1609 r. W drugiej połowie XVI w. pojawiły się pierwsze regulacje sejmowe dotyczące alternatywnej właściwości sądów powszechnych wobec żołnierzy zaciężnych. Rok 1609 nie zakończył rozwoju takich struktur sądowniczych ${ }^{9}$, stanowi jednak wyraźną cezurę. W 1605 r. umarł wszechwładny Jan Zamoyski, a cztery lata później skończył się okres kształtowania prawa wojskowego $\mathrm{w}$ Koronie $^{10}$. Analizowane lata to czas wyodrębnienia nowej grupy społecznej - żołnierzy zaciężnych - i odnajdywania się jej w dotychczasowych strukturach politycznych i prawnych ${ }^{11}$.

\section{Antagonizm szlachecko-żołnierski}

Generalnie wojsko sprawnie aprowizowane mogło przynosić niebagatelne zyski dla osób sprzedających produkty armii ${ }^{12}$. Zaciężny otrzymywał żołd, za który był zobowiązany kupować niezbędne produkty na rynku ${ }^{13}$. Wojsko nie

nego występowali tylko przed sądami wojskowymi. Z. Skoczek, Polskie wojskowe prawo karne w końcu XVI w., „Wojskowy Przegląd Prawniczy” 1935, t. 8, nr 6, s. 115, podkreśla że „rotmistrza wolno było pozwać do sądu powszechnego (...) o ile on był sprawcą".

${ }^{9}$ Kształtowała się ona dynamicznie do końca istnienia I Rzeczypospolitej. Ostatnią zmianą było wprowadzenie cywilno-wojskowych komisji porządkowych funkcjonujących w latach 1790-1792. Organy te sądziły sprawy o odszkodowanie za szkody wyrządzone przez żołnierzy. Por. W. Szaj, Sądownictwo cywilno-wojskowe w okresie Sejmu Czteroletniego, „Studia i Materiały do Historii Wojskowości” 1984, t. 27, s. 169-175; J. Sobczak, W sprawie organizacji i działalności sądów komisji porządkowych cywilno-wojskowych (1790-1792), „Studia i Materiały do Historii Wojskowości” 1988, t. 30, s. 351-359.

${ }^{10}$ Por. G. Błaszczyk, Artykuly wojskowe i ich rola dla ustroju polskich sił zbrojnych i prawa wojskowego (do końca XVII wieku), „Czasopismo Prawno-Historyczne” 1979, t. 21, nr 2, s. 90-93; zob. Jana Zamoyskiego, hetmana wielkiego koronnego, artykuly wojenne, [w:] Polskie ustawy i artykuly wojskowe od XV do XVIII wieku, wyd. S. Kutrzeba, Kraków 1937, s. 340-350; Artykuly wojenne hetmańskie autoritate sejmu aprobowane, [w:] ibidem, s. 168-206.

${ }^{11}$ A. Mączak, Społeczeństwo polskie od połowy XV wieku do rozbiorów, [w:] Społeczeństwo polskie od X do XX wieku, Warszawa 1988, s. 313; M. Plewczyński, Żotnierz jazdy obrony potocznej za czasów Zygmunta Augusta. Studia nad zawodem wojskowym w XVI w., Warszawa 1985, s. 7.

${ }^{12}$ Znamienne, że pogląd o uciążliwości wojska, podkreślany przez cały okres trwania Rzeczypospolitej, skończył się wraz z rozbiorami, gdy armię utrzymywano w karności, zapewniając sprawny system zaprowiantowania. Ludność cywilna domagała się jak najliczniejszej obecności żołnierzy, którzy przynosili zysk całej prowincji. Tak widzieli tę kwestię mieszkańcy Galicji, pod rządami Habsburgów. Memoriał z 23 IV 1790 r., [w:] Projekt konstytucji dla Galicji z 1790 r. („Charta Leopoldina”), wyd. i tłum. S. Grodziski, A. S. Gerhardt, Warszawa - Kraków 1981, s. 49-51.

${ }^{13}$ Mogły być one dostarczone do wojska przez kupców, specjalnych urzędników wojskowych bądź przez same roty. H. Kotarski, Wojsko polsko-litewskie podczas wojny inflanckiej 1576-1582. Sprawy organizacyjne, cz. 4, „Studia i Materiały do Historii Wojskowości” 1971, t. 18, nr 1, s. 38-39, 57; H. Wisner, Prowiantmistrz w Wielkim Księstwie Litewskim 1621-1622, [w:] Między Zachodem a Wschodem. Rzeczypospolita XVI-XVIII wieku. Studia ofiarowane Zbigniewowi Wójcikowi w siedemdziesiąta rocznice urodzin, Warszawa 1993, s. 87-92. 
mogło również stacjonować i wybierać żywności z dóbr szlacheckich ${ }^{14}$. Szybko jednak niewydolny system finansowy doprowadził do zmiany postaw żołnierzy ${ }^{15}$. Coraz częściej pozbawieni żołdu zaciężni dopuszczali się grabieży i wymuszeń na ludności cywilnej ${ }^{16}$. Powodowało to niezadowolenie szlachty ${ }^{17}$, która na własnym budżecie odczuwała niekarność wojska ${ }^{18}$. Nawet chłopi i mieszczanie doprowadzeni do rozpaczy dopuszczali się ataków na żołnierzy ${ }^{19}$.

Problematyka wywoływała ogromne emocje i kontrowersje. $Z$ jednej strony hetmani stosowali konsekwentną politykę zmierzającą do zapewnienia

${ }^{14}$ S. Starowolski, Prawy rycerz, wyd. J. Turowski, Kraków 1885, s. 15; T. Ostrowski, Prawo cywilne albo szczególne narodu polskiego, t. 1, Warszawa 1784, s. 101-103; W. Skrzetuski, Prawo polityczne narodu polskiego, t. 1, Warszawa 1982, s. 188; L. Dudek, Rozmieszczenie i zakwaterowanie wojsk $w$ dawnej Polsce, „Przegląd Kwatermistrzowski” 1972, nr 1, s. 112. Szlachta ciągle domagała się realizacji tych praw: „Abyśmy my w majętnościach swoich od Panów żołnierzów wolni byli i angarii tych od nich nie cierpieli". Scriptores Rerum Polonicarum (dalej: SRP), t. 18, Diariusze sejmowe r. 1585, wyd. A. Czuczyński, Kraków, s. 35.

${ }^{15}$ Około 90\% skarbu przeznaczano na utrzymanie wojska (J. Wimmer, $Z$ zagadnień ekonomiki wojskowej XV-XVIII w., Warszawa 1974, s. 58), co wobec niechęci szlachty do płacenia podatków (J. Maciszewski, Szlachta polska i jej państwo, Warszawa 1986, s. 87) prowadziło do systemowych zaległości płatniczych.

${ }^{16}$ Z. Z. Socha, Hiberna. Studium z dziejów skarbowości w dawnej Polsce, Lwów 1937, s. 20; W. Pałucki, Drogi i bezdroża skarbowości polskiej XVI i pierwszej połowy XVII w., Wrocław - Warszawa - Kraków - Gdańsk 1974, s. 132. O skali zjawiska mogą świadczyć dane wskazujące, że wojsko mogło zniszczyć lub zabrać nawet $90 \%$ plonów. Z. Guldon, Zniszczenia gospodarcze w królewszczyznach sandomierskich $w$ dobie rokoszu Zebrzydowskiego (1606-1609), „Kwartalnik Historii Kultury Materialnej” 1982, t. 30, nr 3-4, s. 336-339.

${ }^{17}$ Szlachta skarżyła się: „Rota jedna (...) koło Wolborza w maiętnościach moich plądrowali, bydła sobie gwałtem brali i do tego wsiom kazali się okupować". SRP, t. 20, Diariusze sejmowe r. 1597, wyd. E. Barwiński, Kraków 1907, s. 37-38.

${ }^{18}$ Szczytowe okresy napięć to lata 1566-1570, 1582-1583 i 1590-1591. W latach 60. XVI w. mamy do czynienia z zaległościami finansowymi wobec wojska koronnego walczącego na Inflantach. Apogeum walki o wypłatę żołdu stała się konfederacja radomska z 1570 r. J. Urwanowicz, Wojskowe „sejmiki”. Koła w wojsku Rzeczypospolitej XVI-XVIII wieku, Białystok 1996, s. 75-77. Drugi okres wiązał się $\mathrm{z}$ powrotem na Ukrainę armii z wypraw batoriańskich. Żołnierze, przyzwyczajeni wojnami z Moskwą do grabieży, doprowadzili do wielkiego niezadowolenia wśród szlachty. By uspokoić obie strony, hetman wydał artykuły hetmańskie regulujące tę kwestię („przyjechałem beł dla niebezpieczeństw tych krajów, gdzie, zastawszy niemało kontrowersji u braci między obywatelami ziem ruskich a ludźmi żołnierskimi”). Jana Zamoyskiego hetmana koronnego artykuły żolnierskie, [w:] Polskie ustawy, op. cit., s. 163; por. L. Kieniewicz, Senat za Stefana Batorego, Warszawa 2000, s. 184. Lata 90. to czas konfederacji niepłatnego żołnierza, dodatkowo manipulowanego przez hetmana wielkiego koronnego, wykorzystującego armię w rozgrywkach z Zygmuntem III. M. Ciara, Konfederacje wojskowe w Polsce w latach 1590-1610, „Studia i Materiały do Historii Wojskowości” 1988, t. 31, s. 63; Z. Spieralski, Jan Zamoyski, Warszawa 1989, s. 40.

${ }^{19}$ W 1590 r. Stanisław Żółkiewski skarżył się Janowi Zamoyskiemu: „Białoczerkiewscy barzo zuchwale tractuią te roty, ktore tam są. Przyiachał tu wczora w wieczór Pan Broniowski sam, ktory mi dał sprawę, ze bez wszej przyczyny zebrawszy się uderzyli na gospodę towarzyszów Pana Bohowitynowych, i zabili trzech rodzonych bracziej i czwartego sługę ich. Oczywiście mieszczanie skarżyli się bardzo o wielkie krzywdy". S. Żółkiewski, Listy Stanisława Żółkiewskiego 1584-1620, wyd. T. J. Lubomirski, Kraków 1868, s. 13. 
żołnierzom privilegium for ${ }^{20}$, $\mathrm{z}$ drugiej stan szlachecki dążył do przejęcia sądownictwa w sytuacjach, gdy żołnierze dokonywali przestępstw i deliktów na ludności cywilnej ${ }^{21}$.

Formalnie zapobiegać tym działaniom miałhetman ${ }^{22}$. Jan Zamoyski próbował walczyć z rozpowszechniającym się zjawiskiem nie tylko poprzez sankcje karne ${ }^{23}$, ale również $\mathrm{w}$ sposób systemowy: wprowadzając kwity rotmistrzowskie ${ }^{24}$, próbując utworzyć stały urząd prowiantmagistra ${ }^{25}$.

Praktycznie to sądownictwo i utrzymanie dyscypliny stanowiło remedium na postępowanie żołnierzy wobec ludności cywilnej ${ }^{26}$. Nominalnie sądzić podwładnych powinien rotmistrz lub w jego zastępstwie porucznik ${ }^{27}$. Faktycznie

${ }^{20}$ Szczególną rolę odgrywał Jan Zamoyski, przy pomocy wojska utrzymujący swą niezwykle wysoką pozycję. G. Błaszczyk, op. cit., s. 90-91. Stwierdzał stanowczo: „Hetman żołnierza karać ma i jemu władza dana jest na żołnierza i samże z niego powinien sprawiedliwość, nie szukając jej z niego kędy indziej". SRP, t. 20, s. 81, 94; por. J. Rzońca, Sejm z lat 1597 i 1598, cz. 1. Bezowocny sejm z 1597 roku, Warszawa - Wrocław 1989, s. 70-72. Wyjątkowo wręcz uregulowana była pozycja sądów wojskowych w stosunku do ludności cywilnej w Jana Zamoyskiego hetmana koronnego artykułach żołnierskich, op. cit., s. 163-168. Artykuł 25 upoważniał sędziego do wystosowania żądania do szlachcica o ukaranie poddanych, którzy uczynili szkodę lub krzywdę żołnierzom. W razie odmowy sprawę przekazywano hetmanowi. Tak skonstruowane prawo wskazuje, iż zamysłem J. Zamoyskiego było poddanie wszelkich spraw pod sądownictwo wojskowe.

${ }^{21}$ Por. T. Ostrowski, op. cit., s. 106-108; J. Kamiński, Historia sq̨downictwa, s. 100-101; W. Organiściak, $Z$ badań nad zagadnieniem, s. 102; idem, Kodeksy wojskowe, s. 178-179; P. Gawron, Żolnierz i trybunaty w siedemnastowiecznej Koronie, „Zeszyty Prawnicze UKSW” 2007, t. 7, nr 1, s. 294-295.

${ }_{22}$ Por. Diariusz sejmu lubelskiego 1566 roku, oprac. I. Kaniewska, Wrocław 1980, s. 7; H. Lulewicz, Gniewów o unię ciagg dalszy. Stosunki polsko-litewskie w latach 1569-1588, Warszawa 2002, s. 315; A. Filipczak-Kocur, Sejmik sieradzki za Wazów (1587-1668), Opole 1989, s. 66.

${ }^{23}$ Jan Zamoyski tłumaczył się, że „żadnych ekscesów ani tych gwałtów dopuszczam, i owszem karzę takowe surowie". SRP, t. 20, s. 80.

${ }^{24}$ Jana Zamoyskiego hetmana koronnego artykuly żolnierskie, op. cit., art. 8, s. 165. W chwilach wypłaty żołdu, rotmistrz i pisarz polny miał potrącać odpowiednią kwotę. W związku z „,częstymi skargami i usilnym staraniem posłów Ziem Ruskich i Podolskich, postanowiono jeszcze raz zawrzeć tożsame treści, w konstytucji sejmowej". Volumina Legum, t. 2, wyd. J. Ohryzko, Petersburg 1859 [reprint: Warszawa 1980], s. 264 (dalej: VL).

${ }^{25} \mathrm{~J}$. Rzońca, op. cit., s. 73. Zob. postulaty zawarte u J. Tarnowskiego, Consilium rationis belicae, wyd. T. M. Nowak, Warszawa 1987, s. 47-49 i epizod istnienia tegoż urzędu w okresie wojen batoriańskich: Źródła dziejowe, t. 9. Księgi Podskarbińskie z czasów Stefana Batorego 1576-1586, cz. 2, wyd. A. Pawiński, Warszawa 1881, s. 293; H. Kotarski, op. cit., s. 8-9, 38-39.

${ }^{26}$ Była to powszechna opinia, która odzwierciedlenie znalazła w przysłowiu: „Żeby żołnierz był dobry, lubo zły bardziej jest w hetmanie niż w żołnierzu, żeby słudzy byli dobrzy, bardziej w Panie niż w sługach należy". R. Gałaj, Wojsko w siedemnastowiecznych przysłowiach polskich zebranych przez Salomona Rysińskiego i Andrzeja Maksymiliana Fredrę, „Szczecińskie Studia Historyczne” 2000, nr 12, s. 60 .

${ }^{27}$ Jana Zamoyskiego hetmana koronnego artykuły żotnierskie, op. cit., art. 2, s. 164; por. J. Urwanowicz, op. cit., s. 64. Należy podkreślić twierdzenie W. Organiściaka, Ze studiów nad reforma prawa wojskowego za czasów Stanisława Augusta, „Czasopismo Prawno-Historyczne” 2001, t. 53, nr 1, s. 198, iż do kodyfikacji wojskowej z 1775 r. stosowano w wojsku zwyczaj, który zezwalał na „bezkarne zabijanie występnych żołnierzy przez odpowiadających za nich oficerów". 
jednak dowódcy nierzadko sami byli prowodyrami grabieży, a w najlepszym razie chronili własnych podwładnych. Mikołaj Rej opisuje „sprawiedliwość" czynioną przez rotmistrza na grabiących zaciężnych:

...z kijem za draby biega na koniku:

- Więceś się to polepszył, zły nieślachetniku!

Lecz wżdy daj ze dwie (gęsi) na łęk, a niechaj już więcej,

Bo wierę cie uderzę, niż drugiego, prędzej!28

Ponadto często żołnierze pozostawieni byli bez „opieki”. Skarżono się, że „panowie rotmistrze i porucznicy, ba i towarzysze przedniejsi od rot odjechali, nie masz komu donosić takich dolegliwości i swej wolej hamować, której młodzi bez starszego radzi zażywają"29. Dlatego też zwracano się do samego hetmana z prośbą o „czynienie sprawiedliwości” ${ }^{30}$. Ta nie była szybka ${ }^{31}$, co prowadziło do ingerencji sejmu $\mathrm{w}$ tej materii. Zobowiązano głównodowodzącego do osądzenia swoich podopiecznych w dwa tygodnie od otrzymania skargi ${ }^{32}$, a rotmistrzów do natychmiastowego karania podwładnych ${ }^{33}$. Dowódca sądził trybem przyśpieszonym, gdy oskarżony nie był szlachcicem osiadłym służącym w stopniu towarzysza ${ }^{34}$ i rodzaj przestępstwa nie wymagał, $\mathrm{w}$ świetle przepisów szczegółowych, sądownictwa doraźnego ${ }^{35}$.

${ }^{28}$ Poeci żołnierzom 1410-1945. Antologia, wyd. J. Kapuścicki, W. J. Podgórski, Warszawa 1970, s. 21. Z licznych przypadków końca XVI w. możemy wskazać na Martinusa Borka, który w grudniu 1589 r. chciał ze swoją rotą wjechać do miasta Sandomierza, a wobec oporu mieszczan przez trzy dni plądrował przedmieście. K. Michałowski, Diariusz życia, [w:] Antologia pamiętników polskich XVI wieku, R. Pollaka (red.), S. Drewniak, M. Kaczmarek, Wrocław - Warszawa - Kraków 1966, s. 257.

${ }^{29}$ List Lwa Sapiehy do Jana Zamoyskiego z 11.01.1603 r. Archiwum domu Sapiehów, t. 1. Listy z lat 1575-1606, wyd. A. Prochaska, Lwów 1892, s. 364. Por. S. Żółkiewski, op. cit., s. 37.

${ }^{30}$ SRP, t. 20, s. 80; Archiwum domu, s. 55, 434.

${ }^{31}$ Pomimo ciągłych deklaracji hetmanów, praktyka była zupełnie odmienna. Hetmani „między sobą” pisali o swawoli w ciągnieniu: „A niebaczę inaczej jedno skarać kogo”. Nie odwoływano się do krzywdy cywilów, lecz na „stratę iaką (strzeż Boże) w ludziach [tj. żołnierzach] przyjdzie sobie obiecować". Nadrzędnym celem, co nie dziwi, było utrzymanie armii w pełnym składzie, dobrych nastrojach i dyscyplinie, nie zaś ochrona ludności cywilnej. S. Żółkiewski, op. cit., s. 112.

${ }^{32}$ VL, t. 2, s. 262. Pamięta o tym jeszcze T. Ostrowski, op. cit., s. 107.

${ }^{33} \mathrm{VL}$, t. 2, s. 262. Rotmistrzowie mieli ogromne prerogatywy sądowe, pozwalające na zasądzenie kary śmierci. Wprost formułują to Jana Zamoyskiego hetmana koronnego artykuły żołnierskie, op. cit., art. 2, s. 164, przyznając te kompetencje również porucznikom. Nie istniał zakaz skazywania towarzyszy na śmierć przez rotmistrzów, jak chcą J. Karwin, E. Pomiarowski, S. Rutkowski, Z dziejów wychowania wojskowego w Polsce od początku państwa polskiego do 1939 roku, Warszawa 1969, s. 63. Należy podkreślić, iż Florian Zebrzydowski nie przyznawał rotmistrzom prawa do skazywania towarzyszy na śmierć lub skuwania łańcuchem. Jednakże i w tym przypadku istniały wyjątki: Pouczenie wojenne, przesłane przez Floriana Zebrzydowskiego Mikołajowi Radziwiłłowi, [w:] Polskie ustawy, op. cit., s. 86.

${ }^{34}$ VL, t. 2, s. 288. Uznawano jednak szlachectwo cudzoziemskie, bez indygenatu. Wówczas nie wymagano posiadania ziemi.

${ }^{35}$ Przykładem XVI-wiecznej normy, nakazującej natychmiastowe karanie, jest przepis prawny dotyczący grabieży. Zapobiegając swawoli czeladzi, oficerowie złapanych „szubienicą zaraz bez miłości 
Wśród norm prawa wojskowego rotmistrz zobowiązany był sądzić i karać bez zwłoki wyłącznie przestępstwa uderzające $\mathrm{w}$ ludność cywilnąa ${ }^{36}$. W razie braku działań dowódcy, szlachcic mógł wystąpić przeciwko niemu do jego przełożonego albo niżej opisanych sądów, a wobec niezadowalającego dekretu zgłaszał apelację $e^{37}$.

Jak system sądownictwa wojskowego działał w praktyce - w sytuacjach, gdy pokrzywdzono osobę cywilną - prezentuje, wywodzący się z drobnej szlachty małopolskiej, Jakub Zawisza ${ }^{38}$. Przyznawał on, iż „artykuły hetmańskie dosyć ostre na piśmie ale w rzeczy samej tylko sie coś nad pacholiki i hajduki pokazuje”. Dostrzegał, że hetman posiadał szerokie kompetencje sądowe, któremu „dana jest wielka władza i wielka moc w wojsku i jest iudex ultimae instantiae”.

Podkreślałjednak koniecznośćfunkcjonowania alternatywnego sądownictwa powszechnego, gdyż władza hetmanów i sędziów wojskowych „jeno (...) nad żołnierzami et his, qui castra sequuntur, rozumie. Ale nienależnemu pod władzą hetmańską człowiekowi, kiedy mu się krzywda od żołnierza stanie a nie kontentując sie $\mathrm{z}$ dekretu hetmańskiego, wolna ma być apelacya abo za dworem do K. J. M. abo na trybunał". Tłumaczył tę konieczność stanem faktycznym, gdyż „między żołnierzami, na żołnierza sprawiedliwości dochodzić, wielka trudność i niepodobna, by miał nasprawiedliwszą, aby ją mógł i dobrze wywieść i właśnie otrzymać".

Interesujące są patologie sądownictwa wojskowego, które autor wymienia: „Bo łacniej do fałszu stu brodatych i jakoby poczciwych świadków, niż o jednego do prawdy contra fortunam armati, gdzie wszyscy i przed sądem słowy i zgrzytaniem zębów przegrażają, buzdyganem i czekanem kiwają: śmiałby się ozwać i zeznać, żem widział a przeciwko temu mówić próżno". Wskazuje również na daleko idący solidaryzm żołnierski, który polegał na ujmowaniu się całego wojska za sądzonym towarzyszem. Stąd nie dziwi, że pomimo chęci, hetmani nie byli w stanie wymierzyć sprawiedliwości ${ }^{39}$.

aby był karan na onemuż miejscu”. Norma ta wskazywała sankcję bezwzględnie obowiązującą. Ponadto doraźność wykonania sprawiedliwości podkreślona jest natychmiastowością powieszenia na miejscu złapania. Jana Zamoyskiego hetmana wielkiego porzadek $w$ ciagnieniu $z$ leż, [w:] Polskie ustawy, op. cit., art. 7, op. cit., s. 161-162; por. J. Sikorski, „Księgi hetmańskie” Stanistawa Sarnickiego na tle piśmiennictwa wojskowego w Polsce XVI wieku, cz. 2, „Studia i Materiały do Historii Wojskowości” 1967, t. 13, nr 1, s. 26.

${ }^{36}$ Były to: najazd na dom szlachcica, zajmowanie pracą chłopów szlacheckich, sprzedaż napojów ze szkodą dla szlachcica przez szynkarki, kradzież ryb ze stawów szlacheckich, wydarcie żywności przemocą, podbieranie miodu, kradzież drewna. Jana Zamoyskiego hetmana koronnego artykuły żołnierskie, op. cit., art. 10, 13, 17, 19, 21, 23, 24, s. 165-166.

${ }^{37}$ Rozróżnienie dwóch trybów czynienia sprawiedliwości przewiduje konstytucja z 1588 r. O żołnierzach, VL, t. 2, s. 288.

${ }^{38}$ J. Zawisza, Wskrócenie prawnego procesu koronnego 1613, wyd. A. Winiarz, Kraków 1899, s. 39-40.

${ }^{39}$ „Acz J. Mć p. Hetman polny, który był między nami, z tym się opowiadał, że każdemu ukrzywdzonemu, który się na żołnierze przed nim skarżył, czynił i czynić jest gotów sprawiedliwość, jednak pp. posłowie mają postanowić pewny i prędki sposób od ucisków żołnierskich". SRP, t. 20, s. 386. 


\section{Cechy sądów ukrzywdzonych}

Opieszałość i stronniczość sądownictwa wojskowego doprowadziły do szukania przez sejmiki ${ }^{40}$ i sejmy ${ }^{41}$ alternatywnych prób rozwiązania problemu. Realizowano je poprzez coraz częstsze konstytucje sejmowe ${ }^{42}$, dotyczące dwóch materii. Po pierwsze, zaostrzano kary za przestępstwa wojskowe ${ }^{43}$. Po drugie, ograniczano właściwości sądów wojskowych do rozpatrzenia spraw, w których stroną oskarżoną był żołnierz.

O ile wojsko nie przejmowało się pierwszymi przepisami, słusznie uznając, że praktyka zweryfikuje normy prawne, o tyle konieczność podporządkowania się cywilnej jurysdykcji odbierało z zaniepokojeniem. Szlachta, jak się okazało, nader chętnie korzystała ze stworzonej przez siebie alternatywnej drogi sądowej ${ }^{44}$. Zaciężni natomiast niechętnie stawali przed tymi organami, twierdząc że traktuje się ich tam bardzo surowo ${ }^{45}$. Próbowali nawet zlikwidować nieodpowiadające im przepisy ${ }^{46}$. Jest to szczególnie widoczne

${ }^{40}$ Tam szlachta nieraz formułowała radykalne postulaty: zlikwidowanie wojsk kwarcianych i przeznaczenie kwoty na upominki dla Tatarów, czy likwidacja służby zaciężnej podczas zimy. SRP, t. 20, s. 379; J. Choińska-Mika, Sejmiki mazowieckie w dobie Wazów, Warszawa 1998, s. 119.

${ }^{41}$ Jak podnosili senatorzy podczas sejmu 1585 r.: „O Rusi o województwie Wołoskim, który się na krzywdy często uskarża. Będzie też skarga (...) na żołnierze”. SRP, t. 18, s. 25.

${ }^{42}$ Związane to było z rozszerzeniem kompetencji sejmu. Miał on zajmować się wszystkim, co dotyczyło Rzeczypospolitej jako całości i wprowadzało zmiany w stosunku do obowiązującego prawa. W tej kategorii spraw, ważne miejsce zajmowała kwestia wojny i organizacji obrony państwa. S. Grodziski, Sejm dawnej Rzeczypospolitej jako najwyższy organ ustawodawczy. Konstytucje sejmowe - pojęcie i próba systematyki, „Czasopismo Prawno-Historyczne” 1983, t. 35, nr 1, s. 163-164. Jeszcze w legacji królewskiej z 1628 r. podkreślano potrzebę powrotu do starego zwyczaju - wyłącznej kompetencji sejmu w sprawach obrony Rzeczypospolitej. S. Płaza, Sejmiki i zjazdy szlacheckie województw poznańskiego i kaliskiego. Ustrój i funkcjonowanie (1572-1632), Warszawa - Kraków 1984, s. 102.

${ }^{43}$ Od połowy XVI do połowy wieku XVII aż w 22 konstytucjach zajmowano się tą kwestią. S. Jurkiewicz, L. Kania, Prawo w ochronie dyscypliny w Polsce przedrozbiorowej, „Wojskowy Przegląd Prawniczy" 1996, t. 69, nr 2, s. 42; G. Błaszczyk, op. cit., s. 93-94 pomiędzy 1590 a 1696 r. naliczył 32 konstytucje.

${ }^{44} \mathrm{O}$ skali zjawiska niech świadczy uniwersał z 1610 r. Stanisława Golskiego: „Spodziewać się pohańców co chwila potrzeba, a żołnierze, na których do kilkaset już pozwów wniesiono, pilniej drzwi prokuratorskich, aniżeli Ukrainy strzec muszą". W. Łoziński, Prawem i lewem. Obyczaje na Czerwonej Rusi w pierwszej połowie XVII wieku, t. 1. Czasy i ludzie, Kraków 1957, s. 138.

${ }^{45}$ E. Janas, Konfederacja wojska koronnego w latach 1661-1663, Lublin 1998, s. 16; W. Organiściak, $Z$ badań nad zagadnieniem, op. cit., s. 102; J. Urwanowicz, op. cit., s. 64.

${ }^{46}$ Tak m.in. król wobec skonfederowanego wojska obiecał nie tylko zapłatę żołdu, ale „konstytucją na sejmie przeszłym przeciw żołnierzom ostro uczynioną (...) żeby auctoritate publica zniesiona była”. SRP, t. 21. Diariusze i akta sejmowe r. 1591-1592, wyd. E. Barwiński, Kraków 1911, s. 102. Podkreślmy, że w 1591 r. wprowadzono bardzo dotkliwy dla żołnierzy przepis, przekazując kompetencje - nadzorcze nad sądami wojskowymi i sądownicze nad zaciężnymi - Trybunałowi Koronnemu. Analogiczna sytuacja dotyczyła zniesienia praw z 1609 r.: „Seim Walny Warszawski w roku 1616 miesiąca kwietnia 26 dnia odprawowany”. Instrukcja I. K. M. na Seymiki Powiatowe, Svenska Riksarkivet (Stokholm), Skoklostersamlingen, Polska Manuskript, sygn. E 8600, k. 458v. 
w XVII stuleciu, gdy wojsko, najczęściej skonfederowane, zaczyna ingerować w prawo Rzeczypospolitej ${ }^{47}$.

Na sejmach, począwszy od 1567 r., znaleziono drugą, obok wojskowej, drogę uzyskania sprawiedliwości ${ }^{48}$. Odtąd spory o wyrządzenie szkód majątkowych lub krzywd ${ }^{49}$, gdy ofiarą był poddany króla, rozstrzygane mogły być przez sądy powszechne. Jakiego rodzaju sprawy należały do właściwości alternatywnej tej grupy sądów? Sprecyzowane przez XVIII-wiecznych prawników oceny trudno przekładać na rzeczywistość wcześniejszą o dwa stulecia ${ }^{50}$.

Aby udzielić odpowiedzi na to pytanie, należy podkreślić, iż w Rzeczypospolitej podział spraw na cywilne i karne wynikał z rodzaju sankcji grożących za popełnienie czynu niedozwolonego. „Cywilne albo padają na majątek lub worek przestępcy, albo na czasowe górne więzienie. Kryminalne ciągną za sobą utratę życia lub części ciała, czci, honoru, dóbr, chłostę na ciele, albo więzienie głębsze" ${ }^{51}$. W tak przyjętej definicji możemy uznać, iż w ogromnej większości sądy ukrzywdzonych dotyczyły spraw cywilnych. Jedynie w ściśle określonych przypadkach, omówionych szczegółowo w kolejnych rozdziałach, żołnierze mogli być pociągnięci do surowych sankcji karnych ${ }^{52}$.

${ }^{47}$ Zob. P. Gawron, op. cit., s. 300-304, gdzie autor ukazuje m.in. starania żołnierzy o zniesienie ich podwójnej podsąaności.

${ }^{48}$ M. Podbiera, Wojskowy postępek sądowy Polski przedrozbiorowej (przyczynek do historii prawa i wojskowości polskiej), Poznań 1925, s. 8.

${ }^{49}$ J. Kamiński, Historia sądownictwa, op. cit., s. 100 oraz W. Organiściak, Z badań nad zagadnieniem, op. cit., s. 102 błędnie wskazują tylko na szkody majątkowe. Tymczasem prócz „szkody” konstytucje wspominają o „krzywdzie”. VL, t. 2, s. 287-288, 327, 330, 390. Zob. patologiczne działania żołnierzy u W. Łozińskiego, op. cit., s. 173: „Nie dość, że wszystko w domu mieszczankowi i chłopkowi ubogiemu żołnierz wybierze, że i skobla nie zostawi, ale się jeszcze nad nędznym człowiekiem pastwi, w kurek mu do rusznicy palce wykręcając, bosymi nogami na węglach sadzając, witkami głowę tak zakręcając, że aż oczy na wierzch wyłażą".

${ }^{50}$ T. Ostrowski, op. cit., s. 106-107: „Sprawy cywilne między szlachtą i żołnierzem, czy ziemskie, czy uczynkowe, szczególnie do sądów szlacheckich należą (...). Te zaś sprawy, które ze służby wojskowej płyną, chociażby nie były kryminalne, ale proste uczynkowe należą do właściwości sądów wojskowych". W. Skrzetuski, op. cit., s. 299: „Sprawy cywilne między obywatelem a wojskowym, należą według stanu osób do sądów ziemskich, grodzkich, lub miejskich z wolnością apelowania do ostatnich instancji podług powszechnych praw królestwa”. S. Brodowski, op. cit., s. 40, 42, 44, 46 podkreśla, że „wszystkie sprawy tak wynikające ze służby wojskowej jak i o charakterze cywilnym powinny rozstrzygać sądy wojskowe"; por. W. Organiściak, Kodeksy wojskowe, s. 174-181.

${ }^{51}$ T. Ostrowski, op. cit., s. 378-379; por. Z. Zdrójkowski, Teodor Ostrowski (1750-1802). Pisarz dawnego polskiego prawa sądowego, Warszawa 1956, s. 68, 111-112; K. Bukowska, Tomasz Drezner polski romanista XVII wieku i jego znaczenie dla nauki prawa w Polsce, Warszawa 1960, s. 161.

${ }^{52}$ Zdają się potwierdzać ten pogląd regulacje tyczące się interesującego nas problemu. Konstytucja z 1591 r. wyróżnia dwa rodzaje przestępstw. Pierwsza grupa oznaczona jest jako civili excessus. Katalog tych wykroczeń został w konstytucji enumeratywnie wymieniony, o charakterze dzisiejszych deliktów. Ustalono w tych przypadkach jedną sankcję w wysokości 14 grzywien za każdą szkodę. Drugim rodzajem był czyn kryminalny sensu stricto - excessus criminali. VL, t. 2, s. 330; zob. rozdział 5 i 6. 
Świadczy o tym również sposób karania występnych. Pierwotnie rotmistrz wobec swoich towarzyszy ${ }^{53}$, później pisarz polny winien wstrzymać wypłatę żołdu, „aby kwit od ukrzywdzonego pokazał, iż dostateczną sprawiedliwość uczynił" ${ }^{54}$. Żołnierze omijali prawo, zmuszając ludność do wystawiania fikcyjnych zaświadczeń ${ }^{55}$. Przeciwdziałając zjawisku, organizowano komisję do zapłaty wojsku (pierwszą w $1591 \mathrm{r}$.), gdzie rozliczenia finansowe $\mathrm{z}$ armią związano z nadzwyczajnymi sądami o szkody poczynione przez żołnierzy. Deputaci i szafarze wyznaczeni przez sejm mieli za zadanie potrącić „od razu” przy wypłacie żołdu zasądzone sumy ${ }^{56}$. Sposób egzekwowania odszkodowania i grzywny przez komisje rozliczające się z wojskiem zdominował XVII-wieczną rzeczywistość, co wskazuje na skuteczność tego rozwiązania ${ }^{57}$.

Dodatkowo komplikowały cały system różne, stosowane przez sądy, systemy prawa. Za to samo przestępstwo sądy wojskowe, w myśl artykułów wojskowych, skazywały nawet na karę śmierci ${ }^{58}$, podczas gdy pozostałe stosowały kary pieniężne ${ }^{59}$. Różnica polegała na różnym charakterze przestępstwa. Dla cywilów czyn żołnierza oznaczał szkodę, za którą należy mu się odszkodowanie. Według prawa wojskowego takie działanie było równoznaczne ze złamaniem dyscypliny, dlatego kara musiała być dotkliwsza ${ }^{60}$. Nasuwa się wniosek, że sądy wojskowe traktowały pozwanego jako żołnierza, a niżej opisane sądy szlacheckie jako szlachcica, stosując wobec niego prawo ziemskie ${ }^{61}$. Poświadcza to dochodzenie sprawiedliwości niemal wyłącznie na rotmistrzach i specjalny katalog kar wymienionych w konstytucjach zaostrzających ogólnie przyjęte sankcje prawa ziemskiego o grzywny i kary na czcíi ${ }^{2}$. Należy zastrzec, że praktyka sądów wojskowych wskazuje na stopniowe łagodzenie litery prawa i wprowadzenie w tych przypadkach, na wzór sądów powszechnych, kar pieniężnych ${ }^{63}$.

${ }^{53}$ VL, t. 2, s. 76; S. Brodowski, op. cit., s. 44.

${ }^{54}$ VL, t. 2, s. 264; por. SRP, t. 20, s. 402; J. A. Jabłonowski, Dwanaście wodzów polskich, Lwów 1754, s. 15.

${ }^{55}$ Biblioteka PAN i PAU w Krakowie, 360, k. 28v-29.

${ }^{56}$ VL, t. 2, s. 327, 330 .

${ }^{57}$ Przykładowo: VL, t. 4, s. 167, 184, 204, 241, 274-275, 323-324, 392. Analogicznie postępowano po 1717 r. S. Brodowski, op. cit., s. 40. Odmiennego zdania był świadek wydarzeń, Joachim Bielski, który twierdził, że „lepiej aby tym podskarbi był (jako bywało pierwej) szafował. Gdyż nie darmo urzędy koronne są". J. Bielski, Kronika, cz. 2, wyd. J. K. Turowski, Ostrów 1856, s. 1651.

${ }^{58}$ Jana Zamoyskiego hetmana wielkiego koronnego artykuly wojenne, op. cit., art. 13, 16, 24, s. 343-344 .

${ }^{59}$ VL, t. 2, s. 330.

${ }^{60}$ M. Podbiera, op. cit., s. 22-23.

${ }^{61}$ Warto przywołać konstytucję z 1642 r., która wyraźnie stwierdza: „Trybunał postępkiem żołnierskim, sądzić nie będzie: ale ordinario processu, iako i inszych obywaltelow stanu szlacheckiego". VL, t. 4, s. 27.

${ }^{62}$ VL, t. 2, s. 330-331, 390, 463.

${ }^{63}$ Zob. wyrok sądu wojskowego z 1678 r. o spalenie i złupienie pięciu zagród chłopskich przez oddział arkebuzerów dowodzonych przez majora Mikołaja Magnusa. Nie zastosowano wobec prowodyrów 
Właściwość alternatywna stworzyła problem podwójnej odpowiedzialności żołnierzy za niedozwolony czyn. De facto nie była to kłopotliwa sytuacja. Sejmy rozszerzyły właściwość rzeczową sądów powszechnych z uwagi na niechęć odpowiednich organów wojskowych do karania podwładnych. Forum zależało od decyzji osoby poszkodowanej. Decydowało pierwszeństwo rozpoczęcia postępowania $^{64}$. Żołnierze żądali jednak rozwiązania tej niejasnej kwestii m.in. W roku $1622^{65}$.

Zakończeniem kształtowania się właściwości sądowej w sprawach o szkody i krzywdy wyrządzone przez żołnierzy szlachcie i ich poddanym był rok $1609^{66}$. Wówczas to ustalono, jak $\mathrm{w}$ zwykłych sytuacjach powinien zachować się pokrzywdzony ${ }^{67}$. Przewidziano ekspresis verbis trzy drogi: złożenie pozwu przed Trybunał Koronny, sąd rotmistrzowski lub hetmański. Pokrzywdzony wybierał forum, ostatecznie jednak przez apelację zawsze mógł odwołać się do najwyższej instancji, czyli trybunału. Nie wspomniano przy tym o sądzie grodzkim, co może wskazywać na jego niewielkie znaczenie ${ }^{68}$.

Powyższy przepis wywołał $\mathrm{w}$ wojsku poruszenie. Żołnierze uznali zawarte $\mathrm{w}$ nim normy prawne za bardzo surowe, dotychczas w prawie niespotykane. Wobec zaległości płatniczych elity szlacheckie $\mathrm{z}$ niepokojem spekulowały w 1610 r., że żołnierze chcą „,confederatią zaraz podnieść, i w niej tak długo trwać gromadą ażby constitutia sejmu przesłego przeciw żołnierzom uczyniona zniesiona była, a dopiero [wówczas - K. Ł.] zapłatę zasłużonego wziąwszy z gromady się roziachać"69. Argumenty żołnierzy starał się zbić Zygmunt III, wskazując na wcześniejsze, analogiczne przepisy ${ }^{70}$. Ostatecznie udało się uchronić dorobek sejmu 1609 r.

kary śmierci przewidzianej w prawie wojskowym, lecz karę pieniężną w wysokości 5 tys. zł. Biblioteka Zakładu Narodowego im. Ossolińskich we Wrocławiu, rkps 11801/III, s. 627-629.

${ }^{64} \mathrm{VL}$, t. 2, s. 327.

${ }^{65}$ Punkta od wojska poddane do sejmu 1622, [w:] Pamiętniki historyczne, t. 2, wyd. L. Hubert, Warszawa 1861, s. 7-8; J. Pietrzak, Konfederacja lwowska w 1622 roku, „Kwartalnik Historyczny” 1973, t. $80, \mathrm{nr} 4$, s. 849,866 .

${ }^{66} \mathrm{VL}, \mathrm{t} .2$, s. 463.

${ }^{67}$ Zarówno Trybunał Radomski, jak i powoływane ad hoc komisje do zapłaty wojsku i sądzenia przestępstw żołnierskich miały nadzwyczajny charakter.

${ }^{68}$ Wątpliwej natury są przykłady sądów grodzkich, czyniących na początku XVII w. sprawiedliwość, podane przez M. Podbierę, op. cit., s. 13-14, gdyż pozwani żołnierze służyli w wojskach prywatnych. Odmiennego zdania jest W. Łoziński, op. cit., s. 175, który w oparciu o księgi grodzkie stwierdził: „Mnóstwo o to [przestępstw żołnierzy - K. Ł.] pozwów i protestacyj”.

${ }^{69}$ A. Baranowski do W. Gembickiego, Skwiezniewic 14. 02. 1610, Svenska Riksarkivet (Stokholm), Extranea IX Polen, sygn. 95, teczka Albertus Baranowski till Laurentius Gembicki (niepaginowana).

${ }^{70}$ Nie rożneć dzisiejsze prawa od dawno starożytnych Polskich zwyczajów kto się im przypatrzy. Respons od Jego K Mci dany pod Smolenskiem PP. Posłom Rycerstwa Inflantskiego dany 17. 03. 1610, Svenska Riksarkivet (Stokholm), Skoklostersamlingen, Polska Manuskript, sygn. E 8597, k. 147. 
Generalnie omawiane możliwości procesowe przyznano szlachcie, choć sejm w $1591 \mathrm{r}$. przewidział również sposób dochodzenia sprawiedliwości przez miasta i wsie ${ }^{71}$. Właściwe postępowanie sądowe poprzedzało wówczas dochodzenie przed panem, ewentualnie dzierżawcą. Dopiero, gdy szlachcic uznawał roszczenia swych poddanych, stawiając swoją pieczęć na pozwie do sądu, skarga była przyjęta.

W 1567 r. wprowadzono zasadę konsekwentnie stosowaną w późniejszych aktach prawnych ${ }^{72}$, że poszkodowany oskarża nie osobę, która dokonała przestępstwa, ale rotmistrza lub porucznika oddziału, w którym występny służy ${ }^{73}$. Uzasadniano to nakazem obecności przy rotach i obowiązkiem nadzoru nad podległą jednostką ${ }^{74}$.

Rozwiązanie było do przyjęcia również z powodu sankcji opartych głównie na karach pieniężnych. Zasadniczo odszkodowanie lub grzywnę rotmistrze powinni opłacić $\mathrm{z}$ żołdu ${ }^{75}$ oraz oddając zrabowane towary ${ }^{76}$. W dalszej kolejności należności pozyskiwano $\mathrm{z}$ majątku dowódcy ${ }^{77}$. Był to skuteczny sposób egzekucji, który prowadził jednak do powszechnego niezadowolenia żołnierzy ${ }^{78}$.

${ }^{71}$ Mimo, iż miała ona charakter nadzwyczajny, mogła odzwierciedlać stosowaną praktykę. VL, t. 2, s. 327. Zob. pozew przed Trybunał Lubelski z 1650 r. przeciwko towarzyszom chorągwi tatarskiej i wołoskiej Jeremiego Wiśniowieckiego z powództwa poddanych ze wsi, należących do braci Gidzińskich, o szkody poczynione w czasie leży zimowych. AGAD, Zbiór Aleksandra Czołowskiego, sygn. 17, s. $1-2$.

${ }^{72}$ VL, t. 2, 76, 232, 261, 287, 330-331, 390.

${ }^{73}$ S. Brodowski, op. cit., s. 44; por. J. Rzońca, op. cit., s. 72; K. Bukowska, op. cit., s. 112.

${ }^{74}$ Por. U. Augustyniak, W stużbie hetmana i Rzeczypospolitej. Klientela wojskowa Krzysztofa Radziwiłła (1585-1640), Warszawa 2004, s. 92-94, aczkolwiek pominięto ustalenia zawarte w konstytucjach. Nie można zgodzić się z sugestią zawartą u W. Magnuszewskiego, $Z$ dziejów elearów polskich. Stanisław Stroynowski lisowski zagończyk, przywódca i legislator, Warszawa - Poznań 1978, s. 150, jakoby w tym okresie szerzej nie praktykowano odpowiedzialności dowódców za swych podwładnych.

${ }^{75}$ Jednakże, „iżby też Rotmistrz nie szkodował na tym, gdyż dla występku cudzego żaden karan bydź nie może, gdyby Towarzysz jego szkodę uczynił, ma zachować przy sobie część pieniędzy z zapłaty jego żołnierskiej". VL, t. 2, s. 76. Podobny zapis znajduje się w dokumencie wystawionym przez Zygmunta Augusta rok wcześniej: Diariusz sejmu, op. cit., s. 74; por. J. Sikorski, op. cit., s. 24.

${ }^{76}$ Nie zawsze było to możliwe. Stanisław Żółkiewski jako właściciel dóbr ziemskich relacjonuje: „Skwirku i płaczu od okolicznych ludzi bardzo wiele, i moich poddanych Turczynczan ruszyli także zajęli jem beli nocznem obyczajem kilkanasczie bydła. Urzędnik mój jachawszy do Mostów insze odzyskał, cztery jednak jałowicze przepadły. A szukaiącz ich nalazł u kilku towarzyszów w piwniczach pokryte woły, o których jako ubodzy ludzie niewiedzią czo jem są pobrane. Tak i czy sami czo je pobrali choczby myślili wróczicz niewiedzą komu, bo to nocznem obyczajem biorą niewiedzącz czyje”. S. Żółkiewski, op. cit., s. 36.

${ }^{77}$ VL, t. 2, s. 327.

${ }^{78} \mathrm{~K}$. Tyszkowski, Problemy organizacyjno-wojskowe z czasów wojny moskiewskiej Zygmunta III, „Przegląd Historyczno-Wojskowy” 1930, t. 2, nr 2, s. 292; E. Janas, op. cit., s. 41. Znamienna jest sprawa pomiędzy pisarzem polnym - Wacławem Wąsowiczem, a rotmistrzem - Temrukiem Szymkowiczem. W 1578 r. we Lwowie przy wypłacie pieniędzy urzędnik państwowy potrącił część żołdu dla oficera. Do- 
Kwestia związana z odpowiedzialnością oficerów za swoich żołnierzy koresponduje z zawarowanym $\mathrm{w}$ prawie sposobie obsadzenia stopnia rotmistrzowskiego. Na tym szczeblu nieodzowne było legitymowanie się szlacheckim pochodzeniem oraz posiadaniem nieruchomości ziemskiej ${ }^{79}$. Związane to było z zabezpieczeniem się przed grabieżami zaciężnych i zapewnieniu egzekucji zasądzonych sum ${ }^{80}$.

Wobec wszelkich sądów znajdujących się poza organizacją wojskową, żołnierze mogli stosunkowo łatwo wstrzymać postępowanie, przy pomocy egzempcji wojskowych ${ }^{81}$. Co więcej, w przepisach wyraźnie dopuszczono stosowanie tej instytucji wobec omawianych organów ${ }^{82}$.

\section{Sądy grodzkie}

Ingerencja starosty w szkody wyrządzane przez wojskowych miała długą tradycję. To on $\mathrm{w} X \mathrm{X}$ w. sądził sprawy o zniszczenia dokonane przez pospolite ruszenie $^{83}$. Szczególne uprawnienia otrzymał w stosunku do wojsk zaciężnych dopiero w 1567 r. Ówczesna konstytucja stanowiła pierwszy wyłom w zasadzie privilegium fori żołnierzy zaciężnych ${ }^{84}$. Jeszcze rok wcześniej skargi osób cywilnych po wyprawie wojskowej miał sądzić koronny hetman zaciężny ${ }^{85}$ - Stanisław Cikowski ${ }^{86}$. Jak się jednak wydaje, konfederacja radomska doprowadziła do wykształcenia się nowego zjawiska ${ }^{87}$. Nadal pozostawiono najwyższą

prowadziło to do kłótni między nimi, „aż Timruk zapalony powiedział mu ono słowo, o które się i chłopi w karczmie gniewają". Stąd wynikła bójka i długi spór prawny, rozstrzygnięty polubownie przez Stefana Batorego. Acta historica res gestas Poloniae illustrantia, t. 11. Sprawy wojenne króla Stefana Batorego. Diariusze, relacje, listy i akta $z$ lat 1576-1586, wyd. I. Polkowski, Kraków 1887, s. 125.

${ }^{79} \mathrm{VL}$, t. 2, s. 330, 463. Wcześniejsze konstytucje o analogicznych postanowieniach (m.in. z 1527 roku) miały charakter czasowy. Z. Spieralski, Instrukcje i artykuły hetmańskie Jana Tarnowskiego, „Studia i Materiały do Historii Wojskowości” 1994, nr 36, s. 275.

${ }^{80}$ Tłumaczono: „Ślachciców osiadłych równych nam w prawie, którzy surowością prawa któremu podlegali, bać się muszą i na miłość ojczyzny oglądają się". SRP, t. 21, s. 289.

${ }^{81}$ S. Brodowski, op. cit., s. 44. Dopiero w XVII w. w wyjątkowych okolicznościach ograniczano możliwości stosowania zwolnień odnośnie do przestępstw popełnianych na ludności cywilnej. K. Łopatecki, Egzempcje wojskowe - immunitet żotnierski w Rzeczypospolitej Szlacheckiej XVI-XVII wieku, „Zeszyty Prawnicze UKSW" 2005, t. 5, nr 1, s. 113. O trudnościach w stosowaniu egzempcji przez wojska kwarciane zob. P. Gawron, op, cit., s. 293-300.

${ }^{82}$ VL, t. 2, s. 330; J. A. Jabłonowski, op. cit., s. 16.

${ }^{83}$ J. Rafacz, op. cit., s. 17.

${ }^{84}$ VL, t. 2, s. 76; por. S. Brodowski, op. cit., s. 44 błędnie Z. Skoczek, op. cit., s. 125; pierwszy taki przepis dostrzega $\mathrm{w} 1589 \mathrm{r}$.

${ }^{85}$ M. Plewczyński, Naczelne dowództwo armii koronnej w latach 1501-1572, „Studia i Materiały do Historii Wojskowości” 1991, t. 34, s. 51-53.

${ }^{86}$ Diariusz sejmu, op. cit., s. 66.

${ }^{87}$ Jak nakazywał sejm: „Od żołnierza naszego ukrzywdzonym privatim, bez wiadomości Hetmańskiey, ukazuiem do prawa należnego, kędy szkody y krzywd swoich dochodzić każdemu wolno”. VL, t. 2, s. 261. 
władzę sądową w obozie, w rękach hetmana. Jednakże w czasie pobytu wojska na leżach oraz ciągnienia do obozu lub $\mathrm{z}$ powrotem na stacje, rozszerzono kompetencje sądów powszechnych. Poszkodowany mógł zgłosić się do sądu grodzkiego celem złożenia skargi. Uprawnienie to przysługiwało właścicielom majątków podlegających prawu ziemskiemu oraz ich poddanym. Sądem właściwym miejscowo był ten, w którym pokrzywdzonemu udało się wręczyć pozew rotmistrzowi (tam gdzie go przyścignie uszkodzony).

Właściwość rzeczowa obejmowała jedynie sprawy o szkody i delikty, gdy przestępstwa kryminalne nadal rozpatrywane były przez władze wojskowe ${ }^{88}$. Pozwany musiał stawić się na najbliższych rokach sądowych. Znacznym upośledzeniem rotmistrza był brak możliwości wniesienia apelacji na niekorzystny werdykt.

Na sejmie warszawskim, w 1589 r., zgodnie z zapowiedzią poprzedniego parlamentu ${ }^{89}$, usprawniono powyższe przepisy $^{90}$. Konstytucja ta znacznie doprecyzowała i rozszerzyła zakres regulacji wprowadzony za panowania Zygmunta Augusta. W korzystniejszy dla poszkodowanych sposób, ustalono właściwość miejscową. Sprawa winna odbywać się w sądzie, obejmującym swą jurysdykcją zdarzenie przestępne ${ }^{91}$.

Również składanie pozwu uległo modyfikacji ${ }^{92}$. Wyróżniono dwa tryby:

1) Należało złożyć go w majętności osoby oskarżonej, gdy dobra znajdowały się w tym samym województwie, w którym popełniono przestępstwo;

2) W pozostałych przypadkach, składać dokument należało w gospodzie lub we wsi, w której żołnierzowi przypisane zostały leża zimowe ${ }^{93}$.

${ }^{88} \mathrm{~W}$ tym samym czasie hetman Cikowski sądził przestępstwa popełnione przez zaciężnych. VL, t. 2, s. 76; Diariusz sejmu, op. cit., s. 74, gdzie król stwierdza, iż „około zamordowania lub pobicia niektórych poddanych W.K.L., oraz w przypadkach dezercji lub absencji, sądzić będzie wspomniany hetman”.

${ }^{89} \mathrm{Na}$ sejmie koronacyjnym z $1588 \mathrm{r}$. argumentowano: „Ziemia Wołyńska (...) wielkie szkody od żołnierzow po te czasy odnosiła, postanawiamy (...) żołnierze żadnych leż, przystawstw, i stacyi niemiewali (...). A gdyby się kiedy od żołnierzow komu w braniu żywności i powod, w leżeniu i w ciągnieniu, i w czymkolwiek obraza, ucisk, i szkoda jaka stała: tedy jaki w tym sposób i postępek sobie do dochodzenia krzywd takowych postanowią, takowy na Sejmie, ktory będzie po Koronacji pierwszym, wedle ich żądania i proźby od nich przyjąć będziem powinni”. VL, t. 2, s. 262.

${ }^{90}$ VL, t. 2, s. 287-288.

${ }^{91}$ Potwierdza to VL, t. 2, s. 390.

${ }^{92}$ Według ówczesnej terminologii pozwem nazywano wezwanie pozwanego do sądu lub urzędu w celu dochodzenia prawa. K. Bukowska, op. cit., s. 173.

${ }^{93}$ Nieco inaczej rozwiązano ten problem w sądach trybunalskich. Nie dookreślono konkretnego sposobu składania pozwu, ograniczając się do tego, by „pozwanemu do wiadomości mogło przyść”. VL, t. 2, s. 331. 
Wyraźnie mowa tu o pozwie pisemnym ${ }^{94}$. W konstytucji zapisano również, że składać należy pozew Grodzki $i^{95}$. Oznacza to, iż w dokumencie tym powinien być umieszczony tytuł starosty, a nie króla ${ }^{96}$.

Uległ również rozszerzeniu zakres przedmiotowy spraw rozpatrywanych przez sąd grodzki. Oprócz szkód majątkowych, również „krzywdy” zaznane od żołnierzy miały podlegać wyżej wskazanej właściwości sądowej. Wszystkie jednak miały mieć charakter spraw cywilnych, gdyż zagrożone były jedynie karami pieniężnymi egzekwowanymi „na dobra nieruchome y ruchome, tak y na zasłużone ich pieniądze" ${ }^{\prime \prime}$.

Warto podkreślić, iż dochodzenie sprawiedliwości należało rozpocząć przed sądem rotmistrzowskim. Gdyby rotmistrz nie dokonał sprawiedliwości in instanti, mógł zostać pozwany przed sąd grodzki. W takim przypadku, aby uniknąć kary, musiał przyprowadzić podwładnego lub przysiądż ${ }^{98}$, że oskarżony uciekł przed osądzeniem $\mathrm{z}$ wojska. W przeciwnym przypadku sam osobiście odpowiadał za popełnione przestępstwo. Uciekinier zaś zostawał uznany za dezertera ${ }^{99}$.

Gdyby przestępstwo popełnił towarzysz, będący szlachcicem-posesjonatem, wolno było go osobiście pozwać przed sąd ${ }^{100}$. Mamy tu do czynienia z połączeniem szlachectwa, posiadanej ziemi oraz stopnia towarzysza. $\mathrm{W}$ takim zakresie prawodawca odstąpił od zasady pozywania przed sądy grodzkie jedynie rotmistrzów.

${ }^{94} \mathrm{~W}$ pozwie należało przedmiot roszczenia dokładnie opisać. W sprawach cywilnych powinna być oznaczona w gotówce wysokość roszczenia, pod groźbą niesprawności pozwu. W. Wołodkiewicz, Nieznana rozprawa z XVII w. o pozwie w prawie rzymskim i polskim, „Czasopismo Prawno-Historyczne” 1959 , t. 11, nr 2, s. 56-58.

${ }_{95} \mathrm{VL}, \mathrm{t}$. 2, s. 288.

${ }^{96}$ W. Wołodkiewicz, op. cit., s. 55-56.

${ }^{97}$ VL, t. 2, s. 288; S. Brodowski, op. cit., s. 161.

${ }^{98} \mathrm{Nie}$ stanowiło to poważnego niebezpieczeństwa dla dowódcy. Deprecjację roli przysięgi jako środka dowodowego opisuje M. Kromer, Polska, czyli o położeniu, ludności, obyczajach, urzędach i sprawach publicznych królestwa polskiego księgi dwie, tłum. S. Kazikowski, oprac. R. Machwiński, Olsztyn 1984, s. 89-90: „Szlachta zawsze dbała wielce o zacność i honor. Zdradę, niedotrzymanie obietnicy, krzywoprzysięstwo, kłamstwo zawsze poczytywano i obecnie poczytuje za rzecz haniebną i bezecną, jakkolwiek większa dziś panuje chciwość i niekarność". W armii zaś patrzono na tę instytucję zupełnie racjonalnie: „Przysięga nie zda mi się potrzebna, bo kto zapomni na podściwość, pewnie jeszcze rychlej na Pana Boga przysięgając". Pouczenie wojenne, przesłane przez Floriana Zebrzydowskiego Mikołajowi Radziwiłłowi, op. cit., art. 29, s. 83.

${ }^{99} \mathrm{~W}$ armii koronnej z tego okresu kary oscylowały pomiędzy kwalifikowaną karą śmierci - puszczenie na praszczęta - gdzie na złapanym odbywał się usankcjonowany samosąd żołnierzy z roty dezertera, a karą więzienia. Pouczenie wojenne, przesłane przez Florjana Zebrzydowskiego Mikołajowi Radziwiłłowi, op. cit., art. 22, s. 82; A. Kraushar, Miscellanea archiwalne, Warszawa 1910, s. 35; Akty grodzkie i ziemskie z czasów Rzeczypospolitej Polskiej z Archiwum tak zwanego bernardyńskiego we Lwowie, t. 10, Lwów 1884, s. 1660, poz. 2095.

${ }^{100}$ S. Brodowski, op. cit., s. 44. 
Trzecią możliwością, wcześniej nieznaną, była sytuacja, w której podejrzanym był sam rotmistrz. Oczywiście dowódca nie mógł sam siebie osądzić. Jednakże możliwa była ugoda pomiędzy stronami. Dlatego według powyższych regulacji, poszkodowany powinien upomnieć się o zadośćuczynienie za niezgodny z prawem czyn. Dopiero wobec niepowodzenia ugody poszkodowany mógł wystosować skargę do sądu grodzkiego.

Wszystkie te przypadki wskazują, że przed starostą stawała jedynie szlachta służąca w wojsku lub wyjątkowo doprowadzony przez rotmistrza żołnierz. Słabym punktem powyższych procedur był fakt, iż starostowie grodowi służyli jednocześnie $\mathrm{w}$ wojsku jako rotmistrzowie ${ }^{101}$. Odwoływanie się do sądu grodzkiego, zależnego od starosty, było znaczną słabością tej koncepcji.

\section{Trybunał Koronny}

Na 1589 r. kończą się dalsze modyfikacje związane z sądami grodzkimi ${ }^{102}$. Odtąd sejm skupił się na stworzeniu kolejnej drogi sądowej. W 1591 r. zdecydowano się na wprowadzenie Trybunału Koronnego jako kolejnego organu nadzorującego sądy wojskowe ${ }^{103}$. Pomimo prób zniesienia przez żołnierzy tej zasady, przepisy zostały utrzymane ${ }^{104}$. Szlachta dostrzegała wielką ich wagę i znaczenie w latach późniejszych ${ }^{105}$.

Przyznanie nowych kompetencji trybunałowi zbiegło się z rozszerzeniem w 1589 r. jego zasięgu terytorialnego o województwa: wołyńskie, bracławskie i kijowskie ${ }^{106}$. Na tych ziemiach stacjonowało wojsko, tam też istniało najwięcej spornych spraw wojskowo-szlacheckich. Ponadto widoczna była tendencja do powierzania trybunałowi orzekania $\mathrm{w}$ sprawach bez uprzedniego rozpatrzenia i wydania wyroku przez sąd niższy ${ }^{107}$.

Trybunał był właściwy rzeczowo w sprawach szlachecko-żołnierskich, w których dowódca po wniesieniu skargi nie osądził, ewentualnie nie ukarał

${ }^{101}$ Zapobiegając temu wprowadzono nawet w 1591 r. incompatibilitas starosty z rotmistrzem. Praktyka życia publicznego odbiegała jednak znacznie od litery prawa. VL, t. 2, s. 330; J. A. Jabłonowski, op. cit., s. 18.

${ }^{102}$ Sejm jedynie potwierdzał dotychczasowe ustalenia. VL, t. 2, s. 327, 390.

${ }^{103}$ VL, t. 2, s. 327-331; por. S. Brodowski, op. cit., s. 44; W. Maisel, op. cit., s. 93; J. Rafacz, op. cit., s. 19.

${ }^{104}$ Zob. postulat króla dotyczączy zniesienia omawianych praw i wstępną zgodę ich likwidacji przez sejmiki. SRP, t. 21, s. 102, 187; por. P. Gawron, op. cit., s. 300-304.

105 SRP, t. 20, s. 380 (mimo braku części tekstu, cały kontekst jednoznacznie wskazuje na postulat rozszerzenia kompetencji trybunału na żołnierzy), 402; J. Zawisza, op. cit., s. 39-40.

106 W. Maisel, op. cit., s. 87.

${ }^{107}$ Ibidem, s. 92. 
sprawcy. Oprócz nagrodzenia szkód, pozwany mógł się spodziewać kary sądowej w wysokości 100 grzywien, a niestawiennictwo zagrożone było karą banicji ${ }^{108}$. Podobnie jak przed sądem grodzkim, rotmistrz mógł uwolnić się od odpowiedzialności, przytrzymując na czas rozprawy podwładnych „ślubem” bądź siłą ${ }^{109}$.

Od 1593 r. Trybunał Koronny uzyskał szczególne uprawnienia. Poszkodowanym zagwarantowano, w razie niezadowolenia $\mathrm{z}$ wyroku sądu hetmańskiego, możliwość pozwania rotmistrza przed trybunał ${ }^{110}$. Konstytucja ograniczyła najwyższą władzę sądowniczą hetmana jedynie do osób podlegających prawu wojskowemu ${ }^{111}$. W pozostałych sprawach, w szczególności gdy jedną ze stron był obywatel, wprowadzono nadrzędność sądownictwa szlacheckiego ${ }^{112}$. Stąd rok 1593 stanowi końcowy etap kształtowania uprawnień Trybunału Koronnego, jako najwyższej instancji dla sądów szlacheckich ${ }^{113}$.

Normy prawne, zezwalające na pozywanie przed Trybunał Koronny jedynie rotmistrzów, zostały zmodyfikowane w $1611 \mathrm{r}$., kiedy to rozszerzono zakres podmiotowy na towarzyszy $\mathrm{z}$ klejnotem herbowym ${ }^{114}$. Wydaje się jednak, iż praktyka nie ograniczyła się tylko do żołnierzy pochodzenia szlacheckiego ${ }^{115}$. Rozszerzono również zakres przedmiotowy, który prócz szkód i krzywd wyrządzonych osobom cywilnym, obejmował również: sprzeniewierzenie pieniędzy, sprzedaż osobom trzecim wozów i koni oraz udawanie się do obozu w większej liczbie żołnierzy niż przewidywały listy przypowiednie ${ }^{116}$. Dostrzegamy rozszerzenie nadzoru stanu szlacheckiego nad działaniami

${ }^{108}$ VL, t. 2, s. 390, 463; S. Brodowski, op. cit., s. 44.

${ }^{109}$ S. Kempski, op. cit., s. 194.

${ }^{110}$ VL, t. 2, s. 343; por. K. Tyszkowski, op. cit., s. 285; J. A. Jabłonowski, op. cit., s. 19, 21. Pierwszy raz wprost o apelacji od dekretów hetmańskich mówi konstytucja z 1609 r. VL, t. 2, s. 464; S. Brodowski, op. cit., s. 40, 318; S. Kempski, op. cit., s. 194.

${ }^{111}$ J. Zawisza, op. cit., s. 39.

${ }^{112} \mathrm{O}$ tendencji stawiania wyżej sądów szlacheckich nad wojskowe organy świadczy możliwość pozwania rotmistrza przed sąd trybunalski, który miał wcześniejszy termin rozprawy w sądach wojskowych. VL, t. 2, s. 327.

${ }^{113} \mathrm{O}$ idei stworzenia trybunału piszą: W. Maisel, op. cit., s. 86; S. Ochmann-Staniszewska, Trybunat Koronny lat 1648-1668 w opinii szlachty, „Czasopismo Prawno-Historyczne” 1993, t. 45, nr 1-2, s. 286.

${ }^{114}$ VL, t. 3, s. 8; S. Brodowski, op. cit., s. 318.

${ }^{115} \mathrm{~W}$ praktyce XVII- i XVIII-wiecznej najczęściej pozywano rotmistrzów, poruczników, namiestników oraz urzędników wojskowych, a w autoramencie cudzoziemskim oficerów od stopnia kapitana. Litewskie Państwowe Archiwum Historyczne, f. 8, op. 1, nr 2042, s. 1-12 i 1-79 (podwójna numeracja). Odrębną kwestią zostaje omijanie prawa i wpisywanie do uprzywilejowanego rejestru sług pocztowych i czeladzi obozowej. O Trybunale Koronnym dyskurs anno 1664 spisany, [w:] Pisma polityczne z czasów panowania Jana Kazimierza Wazy 1648-1668, II. 1661-1664, wyd. S. Ochmann-Staniszewska, Warszawa 1990 , s. 267.

${ }^{116}$ VL, t. 2, s. $330-331,343$. 
rotmistrzów nie tylko w sferze sądowniczej, ale związanej z pełnieniem służby wojskowej.

Zagadnienia proceduralne w sądach trybunalskich, gdy stroną był żołnierz, zostały określone dopiero w $1638 \mathrm{r}^{117} \mathrm{~W}$ XVI stuleciu doprecyzowano jedynie sposób składania pozwów ${ }^{118}$. Zaostrzono sankcje, które przeciwdziałać miały obstrukcji prac sądu ${ }^{119}$. Dodatkowo w 1609 r. wyraźnie zaznaczono, że sprawy z żołnierzami należy wpisywać do odrębnego regestru ${ }^{120}$.

Drobne różnice pomiędzy sądem grodzkim a trybunałem, m.in. w formie złożenia pozwu, sankcjach grożącym dowódcom, nie uzasadniały istnienia dwóch równorzędnych forów. Widoczne jest to na przełomie XVI i XVII stulecia, kiedy kompetencje starosty wyraźnie usuwały się na drugi plan. Wzmocnienie pozycji Trybunału Koronnego nastąpiło dodatkowo od 1609 r., kiedy to zobowiązano hetmanów do egzekwowania zasądzonych kar przez ten sąd ${ }^{121}$.

\section{Sądy nadzwyczajne}

Wielkie szkody wyrządzone przez konfederatów w 1590 r. doprowadziły do utworzenia w roku następnym specjalnych sądów doraźnych ${ }^{122}$. Była to reakcja społeczeństwa szlacheckiego na wielkie krzywdy i grabieże dokonane przez swawolnych zaciężnych ${ }^{123}$.

${ }^{117}$ VL, t. 3, s. 442.

${ }^{118}$ Pozew wolno było złożyć w dobrach ziemskich pozwanego lub w miejscu stacjonowania oddziału. Należało tę czynność odnotować w sądach grodzkich. Sąd rozpoczynał prace nie wcześniej niż po miesiącu od doręczenia pozwu. VL, t. 2, s. 331.

${ }^{119}$ Trybunał mógł skazać na banicję w przypadku niestawiennictwa na rozprawę. VL, t. 2, s. 330$-331,390$.

${ }^{120}$ VL, t. 2, s. 464; S. Brodowski, op. cit., s. 40. Regestrum causarum militarium nie doczekał się dotychczas dogłębnego studium, mimo zachowania takowych w archiwach. Zob. Litewskie Państwowe Archiwum Historyczne, f. 8, op. 1, nr 2042, 2043, 2046, 2047, 2048, 2050, 2051, 2053, 2054, 2055, 2056, 2060, 2061, 2064, 2065, 2066, 2069, 2070, 2162, 2163, 2176, 2179, 2180, 2349, 2350.

${ }^{121}$ S. Brodowski, op. cit., s. 40. Należy pamiętać, iż dwa lata wcześniej uchwalono wspólne wykonywanie zapadłych wyroków przez hetmanów i starostów. J. Kamiński, Historia sq̨downictwa, op. cit., s. 103.

${ }^{122} \mathrm{VL}$, t. 2, s. $327,330$.

${ }^{123}$ Świadczy o tym przykład szlachty województwa krakowskiego, której posłowie oprotestowali konstytucję z 1591 r., gdyż część przepisów wprowadzono po zakończeniu obrad sejmu. Posłowie oblatowali w grodach protestację, w której wymienili uchwały, na które stany sejmujące wyraziły zgodę. Nieopatrznie zabrakło tam norm prawnych dotyczących przeprowadzenia nadzwyczajnych sądów nad żołnierzami. Stąd szlachta zebrania na sejmiku proszowickim kilkakrotnie podkreślała, iż zapis ten jest ważny; podsumowując stwierdziła: „A iż niektórzy p. posłowie nasi protestacyą tam uczynieli w akciech grodzkich warszawskich, która wszystkiemu województwu zdała się być niebezpieczna, tak dla nie dołożenia konstytucji o procesie [mowa o sądach nad wojskowymi - K. Ł.], jako i dla inszych defektów, któremi mógłby się kto chcieć szczycić w podnoszeniu sejmu, tedy zdało się wszystkiemu województwu podnieść tę protestacyą". Akta sejmikowe województwa krakowskiego, t. 1.1572-1620, wyd. S. Kutrzeba, Kraków 1932, s. 173-174, 176. 
Organ ten przejął całość przestępstw wojskowych, w których stroną poszkodowaną była jakakolwiek osoba cywilna. „Gwałty, mordy y pożogi y szkody wszelakie” miały być sądzone przez specjalne powołane na sejmie składy sędziowskie ${ }^{124}$. W przypadku skazania zaciężnego na śmierć, infamię lub banicję, przysługiwało odwołanie do sądu sejmowego. Kary pieniężne potrącano z zaległego żołdu, który miał być wypłacony podczas prac tej komisji. W razie gdyby zasądzona suma przekraczała żołd, egzekucja miała się odbywać z dóbr ruchomych i nieruchomych w zwyczajnej procedurze.

Realizując powyższe przepisy, zwołano sąd w 1591 r. (na dzień św. Michała) do Lublina ${ }^{125}$. Starosta lubelski zobowiązany był użyczyć miejsca na odprawienie sądów. Również sąd grodzki zobligowano do udzielenia pomocy procesowej ${ }^{126}$. Deputaci mieli składać przysięgę analogiczną do sędziów trybunalskich, również zapadłe wyroki miały moc dekretów trybunalskich ${ }^{127}$.

W kolejnych dziesięcioleciach XVII w. to sądy nadzwyczajne dominowały przy rozstrzyganiu spraw o szkody i krzywdy popełnione przez wojsko. Powoływano je z reguły łącznie z komisją do zapłaty wojsku. Wynikało to z woli samej, często skonfederowanej, armii. Odwołując się do sądów z lat 1591-1592, podkreślano iż one powinny rozstrzygać wszystkie rodzaje spraw. Być może rozwiązanie to było lepsze $\mathrm{z}$ uwagi na łagodniejsze stosowanie prawa, możliwe że bez uwzględnienia sankcji zagrożonych w prawie wojskowym. Najważniejsze, iż po tym terminie wszelkie przestępstwa ulegały przedawnieniu ${ }^{128}$.

W XVI w. możemy zaobserwować początek sądownictwa rozstrzygającego przestępstwa popełnione przez armię koronną na ludności Wielkiego Księstwa Litewskiego. Przełomowym wydarzeniem był rok 1580, kiedy to na terenie Litwy znaczne szkody ludności cywilnej wyrządził pułk pod dowództwem Marcina Kazanowskiego. Król, nie chcąc utracić poparcia szlacheckiego do dalszych działań z Moskwą, powołał specjalną komisję ${ }^{129}$. Miała ona charakter mieszany: cywilno-wojskowy. Prócz dowódcy pułku zasiąść w niej miał, wywodzący się z Korony, sekretarz królewski Jan Kosmowski i sędzia ziemski miński Marcin Wołodkiewicz. Do ich obowiązków należało zorganizowanie specjalnej sesji sądowej i zawiadomienie o niej zainteresowanych. Podczas prac sądu w obecności rotmistrza lub porucznika, ludność cywilna składała pozwy odnośnie do szkód i krzywd uczynionych przez żołnierzy. Skargi dzielono według rodzaju spraw

\footnotetext{
${ }^{124}$ Praktyka ta utrzymała się w kolejnym stuleciu. E. Janas, op. cit., s. 139-140.

${ }^{125} \mathrm{~J}$. Bielski, op. cit., s. 1651-1652.

${ }^{126} \mathrm{~W}$ praktyce również sądy wojskowe wykorzystywały sądy grodzkie do pomocy procesowej. Biblioteka Zakładu Narodowego im. Ossolińskich we Wrocławiu, rkps 11801/III, s. 629.

${ }^{127}$ VL, t. 2, s. $327,330$.

${ }^{128}$ Punkta od wojska, s. 7, 20.

${ }^{129}$ H. Lulewicz, op. cit., s. 333.
} 
na cywilne (o szkody materialne) i karne (mord, gwalt y inne excessus znaczne). Te pierwsze rozpatrywał powołany przez Batorego sąd, który wymierzał kary grzywny i odszkodowania, według ściśle opisanych w dokumencie stawek.

Sprawy karne wymagały bardziej skomplikowanych procedur. Komisarze mieli udać się na miejsce zdarzenia, gdzie dokonywali scrutinum: zbierali dowody, spisywali pod przysięgą zeznania świadków. Tak zdobyty materiał dowodowy przekazywano, o ile oskarżony żołnierz był szlachcicem-posesjonatą, do sądu wojskowego. W przeciwnych okolicznościach właściwym forum był sąd nadzwyczajny, który miał jednak sądzić na podstawie articulow Riczerskich ${ }^{130}$. Mamy w tym miejscu rzadko poświadczoną w źródłach informację o stosowaniu przez inne niż wojskowe sądy artykułów wojskowych ${ }^{131}$. W obu jednak przypadkach król zastrzegał skazanym możliwość wniesienia apelacji przed swój majestat.

Wyżej omówiona sytuacja nie stanowiła jednostkowego przypadku. Ta bardzo drażliwa dla szlachty litewskiej kwestia w XVII stuleciu była rozwiązywana przez sejmy, które tworzyły lub upoważniały odpowiednie organy do sądzenia szkód i krzywd ${ }^{132}$.

\section{Inne organy sądowe}

Sąd sejmowy, do czasu powstania trybunałów, był najwyższą instancją apelacyjną. Od 1578 r. nie mógł już zmieniać wyroków sądów, w tym wojskowych, $\mathrm{o}$ ile były wydane zgodnie $\mathrm{z}$ prawem ${ }^{133}$. Jednocześnie przyznano prawo pokrzywdzonej szlachcie do subsydiarnego zwracania się do sądu sejmowego, by czynił sprawiedliwość w sprawach karnych ${ }^{134}$. Również sąd sejmowy rozpatrywał sprawy o poddanie twierdzy nieprzyjacielowi ${ }^{135}$. Istniała przy tym właściwość

${ }^{130}$ Biblioteka PAN i PAU w Krakowie, 360, k. 28-29v.

${ }^{131}$ Prawdopodobnie wspomnianymi artykułami rycerskimi były wydane w lipcu 1579 r. w Świrze Articuli omnibus in universum militibus, [w:] Polskie ustawy, op. cit., s. 320-329, będące przeróbką artykułów Jana Tarnowskiego. G. Błaszczyk, op. cit., s. 90.

${ }^{132}$ Przykładowo: VL, t. 4, 167-168 (komisja do zapłaty wojsku powinna sądzić dowódców, którzy przekroczyli granicę Wielkiego Księstwa Litewskiego), s. 186 (oddanie dowódców pod sąd komisji do zapłaty żołdu lub Trybunałowi Koronnemu). Zob. reakcję wojska: Instrukcja posłom od wojska na sejm wysłanym itd. 1666 r., [w:] Pamiętniki historyczne, op. cit., s. 49-50.

${ }^{133}$ S. Ochmann-Staniszewska, op. cit., s. 286.

${ }^{134}$ VL, t. 2, s. 330; por. Z. Skoczek, op. cit., s. 112. Tak w 1597 r. „pan Daniłowicz Rotmistrz JKMci, będąc w kole odniesiony o gwałty w majętnościach szlacheckich czynione, dawał o sobie justyfikacją niewinności swej". SRP, t. 20, s. 91.

${ }^{135}$ A. Lityński, Przestępstwa polityczne w polskim prawie karnym XVI-XVIII wieku, Katowice 1976, s. $58-59$. 
alternatywna $\mathrm{z}$ sądem hetmańskim ${ }^{136}$. Interesujące, że $\mathrm{w}$ odróżnieniu od Wielkiego Księstwa Litewskiego ${ }^{137}$ artykuły wojskowe nie przewidywały kary za poddanie umocnienia. Wskazuje to, iż w większości przypadków rozpatrywano te sytuacje na sejmie.

$\mathrm{Na}$ dworze królewskim i najbliższej okolicy utrzymywali porządek marszałkowie ${ }^{138}$. Ich jurysdykcja obejmowała obszar oddalony nie więcej niż o 1 milę od króla ${ }^{139}$. Mogli oni stosować najsurowsze kary, bez możliwości apelacji ${ }^{140}$. Sądzili w skróconym postępowaniu wszelkie sprawy związane z naruszeniem porządku ${ }^{141}$. Artykuły marszałkowskie wyraźnie określały żołnierzy, jako grupę podległą właściwości sądu marszałkowskiego ${ }^{142}$. Marszałkowie rozstrzygali również sprawy związane $\mathrm{z}$ grabieżami i gwałtami na ludności cywilnej ${ }^{143}$. Jednakże podczas wojny tracili na rzecz sądów wojskowych swe uprawnienia wobec zaciężnych ${ }^{144}$. Osobną grupę stanowili żołnierze nadworni oraz „harcerze”, później określani jako gwardia nadworna, nad którymi pieczę sprawował marszałek ${ }^{145}$.

Bezkrólewie było szczególnym okresem, podczas którego sądy zwyczajne ulegały zawieszeniu146, więc omawiane wyżej sądy nie funkcjonowały. Sejmiki przedkonwokacyjne powoływały własne jurysdykcje zwane sądami kapturowymi ${ }^{147}$. Tam, gdzie stroną poszkodowaną była osoba cywilna, a sprawcą

${ }^{136}$ VL, t. 2, s. 388.

${ }^{137}$ Grzegorza Chodkiewicza hetmana dwornego litewskiego artykuł dla rotmistrzów na zamku $w$ Pernawie, [w:] Polskie ustawy, op. cit., art. 1, s. 116; Grzegorza Chodkiewicza hetmana wielkiego litewskiego artykuły żotnierskie, [w:] Polskie ustawy, op. cit., art. XXXI, s. 135.

${ }^{138}$ M. Kromer, op. cit., s. 124; S. Kutrzeba, Historia źródeł dawnego prawa polskiego, t. 1, Lwów - Warszawa - Kraków 1926, s. 210.

${ }^{139}$ Należy przy tym zaznaczyć, iż obszar czasem mógł być znacznie bardziej rozległy. A. S. Radziwiłł, Pamiętnik o dziejach w Polsce, t. 2. 1637-1646, tłum. i wyd. A. Przyboś, R. Żelewski, Warszawa 1980, s. 390-391.

${ }^{140}$ W. Skrzetuski, op. cit., s. 170.

${ }^{141}$ K. Bukowska, op. cit., s. 170.

${ }^{142}$ Źródła dziejowe, t. 4. Początki panowania w Polsce Stefana Batorego 1575-1577 r. Listy, uniwersały, instrukcje, wyd. A. Pawiński, Warszawa 1877, s. 54.

${ }^{143}$ Acta historica, op. cit., s. 138-139.

${ }^{144}$ J. Piotrowski, Dziennik wyprawy Stefana Batorego pod Psków, wyd. A. Czuczyński, Kraków 1894, s. $49-50$.

${ }^{145}$ Ordynacja dworu Zygmunta III z 1589 roku, oprac. K. Chłapowski, Warszawa 2004, s. 48-50; M. Nagielski, Liczebność i organizacja gwardii przybocznej i komputowej za ostatniego Wazy (1648-1668), Warszawa 1989, s. 5-6; idem, Gwardia przyboczna Władysława IV (1632-1648), „Studia i Materiały do Historii Wojskowości” 1984, t. 27, s. 142-144. Ostatecznie: VL, t. 4, s. 44.

${ }^{146}$ Sądownictwo wojskowe nie podlegało takim ograniczeniom. Warto wskazać na Krzysztofa Myszkowskiego hetmana tempore interregni artykuły dla wojska na granicach śląskich, [w:] Polskie ustawy, op. cit., s. 142 jako przykład wydania praw dla wojska w okresie bezkrólewia. Nastąpiło to z „zezwolenia wszech rad i pp. Koronnych natenczas w Kaskach będących i ze zwoleniem i za proźbą wszech pp. rotmistrzów”.

${ }^{147}$ A. Abramski, Postępowanie przed sądami kapturowymi koronnymi w XVII i XVIII wieku, „Studia iuridicia silesiana” 1986, nr 11, s. 36. 
- wojskowy, przewidziano szczególny tryb wymierzenia sprawiedliwości ${ }^{148}$. Poszkodowany powinien zgłosić skargę rotmistrzowi. W przypadku bezczynności sądu lub w sytuacji, gdy oskarżonym był dowódca oddziału, osoba szukająca sprawiedliwości powinna wnieść skargę do przełożonego armii. Pozew wówczas był skierowany przeciw rotmistrzowi ${ }^{149}$. Gdyby i starszy nad wojskiem nie rozpatrzył sprawy ${ }^{150}$, dowódca mógł zostać pozwany przed sąd kapturowy.

\section{Zakończenie}

Pomiędzy stanem szlacheckim a wojskiem dostrzegamy głębokie antagonizmy. Zaległości płatnicze, niewydolny sposób aprowizacji, relacjednia codziennego coraz bardziej różniły dwa środowiska. Szlachta miała przynajmniej w teorii możliwości polityczne, a wojsko i hetmani - faktyczne do realizacji swych zamierzeń ${ }^{151}$. Zwycięstwem narodu politycznego było stworzenie alternatywnej właściwości sądowej w sprawach, gdy jedną ze stron był obywatel ${ }^{152}$. Mimo kilkakrotnych prób likwidacji przepisów (m.in. z 1593 i 1609 r.) przez wojsko, normy uchwalone na sejmie zostały utrzymane.

Pierwszym organem, który naruszył privilegium fori żołnierzy były sądy grodzkie. Następnie specjalne uprawnienia uzyskał Trybunał Koronny i komisje do zapłaty wojsku. Nie była to jedyna reforma, gdyż wprowadzono zasadę odpowiedzialności dowódców za swych podwładnych. Rotmistrzowie i ich zastępcy posiadali kompetencje sądownicze wobec swych podwładnych, których w praktyce nie realizowali. Stąd sądy grodzkie, Trybunał Koronny i ad hoc powoływane komisje nadzwyczajne dawały możliwość poszkodowanej ludności cywilnej dochodzenia sprawiedliwości z wyłączeniem sądownictwa wojskowego.

${ }^{148}$ Żołnierza zobowiązano do zakupu towarów, „dlatego tak wielki żołd dano. Grożono również a za kimby skarga przyszła o jakie szkody albo gwałty, tedy z takiego będą czynić sprawiedliwość taką, jakby już miała być w zawartym obozie". Krzysztofa Myszkowskiego hetmana tempore interregni artykuły dla wojska na granicach śląskich, op. cit., s. 149.

${ }^{149}$ VL, t. 2, s. 232.

${ }^{150}$ Nie powinien być to okres dłuższy niż dwa tygodnie. VL, t. 2, s. 262.

151 Zorganizowana siła wojskowa mogła całkowicie niweczyć pracę sejmików, sądów i urzędów. Sucho relacjonuje T. Jewłaszewski, Pamiętnik, tłum. E. Ciemniewski, wyd. T. Lubomirski, Warszawa 1860, s. 69-70, że w 1603 r. „zaszła przypadkiem burda pomiędzy sędzią naszym, panem Zenkowiczem, a niejakim Mogilnickim żołnierzem z roty księcia Poryckiego; zaczem rota wróciwszy się ze Zdetela pięć mil stąd odległego, roków nam dosiedzieć nie dała, tak, żeśmy się przed czasem rozjechać musieli”.

${ }^{152}$ Wraz ze wzrostem swawoli żołnierskiej automatycznie następowała reakcja sejmu. Widoczne jest to również w latach 60. XVII w. S. Ochmann-Staniszewska, op. cit., s. 294. 
Szlachta, akceptując kompetencje sądownicze hetmana, nie chciała poddać się pod wojskową jurysdykcję sądową. Po powstaniu Trybunału Koronnego rozpoczęła walkę o przejęcie $\mathrm{w}$ sprawach mieszanych (szlachecko-żołnierskich) najwyższego sądownictwa trybunalskiego. Udało się to w 1593 r., choć i w latach późniejszych szlachta musiała walczyć o utrzymanie wówczas wprowadzonych norm prawnych. Od tego momentu obywatele mogli złożyć apelację od wyroku sądu hetmańskiego na trybunał.

Lata 1567-1609 to okres kształtowania się alternatywnej właściwości sądowej w sprawach cywilów z żołnierzami. Proces nie został definitywnie zakończony ${ }^{153}$, jednak dalsze zmiany dotyczyły jedynie kwestii pobocznych. Należy przy tym podkreślić, że sytuacja międzynarodowa i wewnętrzna w kolejnych dziesięcioleciach sprzyjała wojsku. Długotrwałe działania wojenne i ogromne zadłużenie państwa wobec oddziałów wojskowych, niedowład sądownictwa szlacheckiego, w końcu wykorzystanie egzempcji wojskowych do wstrzymania prac sądów - faktycznie nadawało żołnierzom uprzywilejowaną sytuację prawną w Rzeczypospolitej. Sama szlachta widziała, że zwiększona liczba różnych sądów sprawiedliwości nie przywróci. „Co się w tym dzieje i działo, że na ten domowy rząd dawno nacieramy, u panów go swoich żebrzemy, a jednak im dalej tym więcej nierząd, tym większe excessy, exorbitancye i gravamina (...) odnosimy? Co się w tym działo i dzieje, że się sądziemy urzędy ziemskimi, trybunały, sądy kryminałów mamy, a przedsie nie jednako sprawiedliwości mamy abo odnosimy, nie jednako w przezpieczeństwie, w pokoju pospolitym sobie mieszkamy?" 154 .

Zweryfikować należy wizję audytora wojskowego Samuela Brodowskiego, który w połowie XVIII stulecia, manipulując przykładami, twierdził o pełnym uprzywilejowaniu sądowym żołnierzy ${ }^{155}$. Szlachta w sporze prawnym z żołnierzami mogła swobodnie wybierać forum pomiędzy sądem grodzkim, trybunałem a sądami wojskowymi. Co więcej, szlachcie na wyrok hetmana, najwyższego sędziego wojskowego, przysługiwała apelacja do Trybunału Koronnego.

Sądownictwo konkurencyjne wobec wojskowego dotyczyło zasadniczo spraw o charakterze cywilnym. Wyroki sądowe w tych sprawach można było skutecznie egzekwować poprzez: potrącanie żołdu, egzekucję z dóbr ruchomych i nieruchomych rotmistrzów, rzadziej towarzyszy-posesjonatów. W procesach karnych niepodzielną rolę pełniły sądy wojskowe, choć i w tym przypadku istniały wyjątki, w postaci formowanych ad hoc sądów nadzwyczajnych, sądu sejmowego i niektórych przestępstw rozpatrywanych przez Trybunał Koronny.

\footnotetext{
${ }^{153}$ Ibidem. Przede wszystkim Trybunał Skarbowy zaczął sądzić sprawy o szkody poczynione szlachcie przez żołnierzy. W. Skrzetuski, op. cit., s. 331-332; J. A. Jabłonowski, op. cit., s. 11-12.

${ }^{154}$ SRP, t. 18 , s. 392.

${ }^{155}$ S. Brodowski, op. cit., s. 40, 42, 44, 46, 48; por. W. Organiściak, Kodeksy wojskowe, s. 179-180.
} 
Egzekucję sądową paraliżowały jednak amnestie, nader często pojawiające się w XVII stuleciu oraz opieka prawna hetmana.

Sprawy o szkody i krzywdy poczynione na ludności cywilnej stanowią ciekawy przypadek rozpatrywania tych samych niedozwolonych czynów z perspektywy zupełnie różnych systemów prawnych. Rotmistrzów, czasem towarzyszy sądy szlacheckie traktowały jak szlachtę. Najprawdopodobniej zarówno proces, jak i katalog kar wynikał z przepisów prawa ziemskiego. Tymczasem wojskowy wymiar sprawiedliwości traktował służącą w wojsku szlachtę zupełnie inaczej. Przyjąć należy, że nobilitas mogli być sądzeni prawem wojskowym lub ziemskim, pozostali żołnierze, pozbawieni klejnotu herbowego, byli bezwzględnie podporządkowani sądom i prawu wojskowemu ${ }^{156}$. Te teoretyczne rozważania należałoby zweryfikować poprzez praktykę sądową.

${ }^{156}$ Teza ta zgodna jest z poglądem prezentowanym przez H. Wisnera, Żołnierz a prawo, [w:] Rzeczpospolita Wazów, t. 2. Wojsko Wielkiego Księstwa Litewskiego, dyplomacja, varia, Warszawa 2004, s. $143-154$. 